\title{
Performance of Additive Blended High Volume Fly Ash Concrete - A Systematic Literature Study
}

\author{
T.S. Mukesh ${ }^{1, a^{*}}$, R.K. Shobakiruthika ${ }^{2, b}$, S. Sowmini ${ }^{2, c}$, M. Subaash ${ }^{2, d}$ \\ ${ }^{1}$ Assistant Professor, Department of Civil Engineering, Kongu Engineering College, Perundurai, \\ Erode, Tamilnadu, India \\ ${ }^{2}$ Student, Department of Civil Engineering, Kongu Engineering College, Perundurai, Erode, \\ Tamilnadu, India \\ a*mukesh.sakthivel@gmail.com, bshobakiruthikark@gmail.com, 'sowminisri2017@gmail.com, \\ dsubaashm.17civil@kongu.edu
}

Keywords: Fly Ash, Compressive Strength, Super Plasticizer, Nano-SiO 2 , Splitting Tensile Strength, Flexural Rigidity

\begin{abstract}
Replacing cement with fly ash has recently created huge popularity among the construction field because of its huge production, efficient resources and sustainability aspect. This study is made to determine the High-Volume fly-ash concrete (HVFC) performance by adding additives. The general used concrete mixture is prepared by proportioning fly ash (40-50\%) as a replacement. The concrete specimen was found to have better compressive strengths and hence, passed the strength tests. By incorporating additive $\mathrm{Nano}^{-\mathrm{SiO}_{2}}$ and superplasticizer the following compression, flexural rigidity, splitting tensile strength and elasticity modulus were observed in the specimen to establish the cement and fly ash bond. The concrete performance mix with replacement fly ash at different percent was found to have good compressive strength during test and stayed undamaged during the entire period of exposure.
\end{abstract}

\section{Introduction}

The gigantic increment of populace alongside the enormous improvement these days prompted the extraordinary demand for concrete these days. Kanvic's recommended that the Cement request will raise by around 660 MMT (million metric tons) in India by 2030. Cement which is the essential constituent of concrete contributes the significant $\mathrm{CO}_{2}$ discharge into the climate and furthermore an unnatural weather change. To satisfy the emerging need, in this paper the high-volume fly ash solid execution joining added substances is to be broke down. Fly-ash is collected as residue of coal obtained from power stations. Cement is more expense and important part of concrete. The Cement cost for a unit can be decreased by fractional supplanting of concrete by fly-ash. Fly-ash which is the remains collected from ignition of pummelled coal and gathered from electrostatic power stations wherein coal is used as main fuel source. Fly-ash removal is an important issue as unloading of fly ash as residue might lead to serious ecological issues/risks[1]. The fly ash usage as opposed to unloading it as a non-use material can be mostly utilized on monetary grounds as cement for incomplete substitution of concrete and somewhat in view of its gainful impacts, for example, lower water interest for comparable usefulness, decreased dying and last lower development of warmth. It is being utilized especially in huge applications of solids cum enormous volume situation aiming at controlling development because of hydration warmth and furthermore helps at decreasing breaking at initial ages. HVFC has arisen as development material with its self-potential right. This sort of cement typically contains over half fly-ash by a mass having absolute cement materials nature. Numerous specialists have utilized Class-C and Class-F 
fly-ash in concrete. In the study, an exertion is carried out to introduce the consequences of conducting an examination completed to contemplate the impact of supplanting concrete with $\mathrm{HVFC}$ on the properties of cement and an exertion is made to examine the impact of nano- $\mathrm{SiO}_{2}$ in improving the properties of high strength high HVFC.

\section{Experimental details}

Materials

Cement material used here is Ordinary Portland (grade 43). It adjusted to the prerequisites of IS: 8112-1989, and Table 1, shows the results. The cement utilized here is Type-I cement (ASTM C-150). Fly-ash type Class-F (gravity 2.72) is utilized in this examination. It is tried for compound creation per ASTM C-311, and result is presented in Table 2. Natural sand having a 4.75-mm nominal greatest size is utilized as FA[6]. The coarse aggregate utilized was $12.5 \mathrm{~mm}$ size. The two totals which was tried per IS: 383-1970, and the actual properties along with strainer examination is given in Table 3 and Table 4, individually. A monetarily accessible superplasticizer which is melamine-based was utilized. Nano- $\mathrm{SiO}_{2}$ utilized in this paper was purchased from alpha composites, its real properties are given in Table 5.

TABLE 1: Portland cement characteristics

\begin{tabular}{|c|c|c|}
\hline Test conducted & Obtained Results & $\begin{array}{l}\text { IS: } 8112-1989 \\
\text { Requirements }\end{array}$ \\
\hline $\begin{array}{l}\text { Cement Fineness which is } \\
\text { retained on 90-Am sieve }\end{array}$ & 7.7 & Maximum of 10 \\
\hline $\begin{array}{l}\text { Cement Fineness: specific } \\
\text { surface }\left(\mathrm{m}^{2} / \mathrm{kg}\right)\end{array}$ & 266 & Minimum of 225 \\
\hline Normal consistency & $30 \%$ & - \\
\hline $\begin{array}{l}\text { Vicat setting time (minutes) } \\
\text { Initial time } \\
\text { Final time }\end{array}$ & $\begin{array}{l}107 \\
197\end{array}$ & $\begin{array}{l}\text { Minimum of } 30 \\
\text { Maximum of } 600\end{array}$ \\
\hline $\begin{array}{l}\text { Strength due to Compression } \\
\text { (MPa) } \\
7 \text { days } \\
28 \text { days }\end{array}$ & $\begin{array}{l}34.9 \\
45.1\end{array}$ & $\begin{array}{l}\text { Minimum of } 33.0 \\
\text { Minimum of } 43.0\end{array}$ \\
\hline Specific gravity & 3.15 & - \\
\hline
\end{tabular}


TABLE 2: Fly-ash composition

\begin{tabular}{|c|c|c|}
\hline Chemical parameters & \% of Fly ash & $\begin{array}{c}\text { ASTM C 618 (\%) } \\
\text { Requirements }\end{array}$ \\
\hline Silicon-dioxide, $\mathrm{SiO}_{2}$ & 54.2 & - \\
Aluminum-oxide, $\mathrm{Al}_{2} \mathrm{O}_{3}$ & 25.6 & - \\
Ferric-oxide, $\mathrm{Fe}_{2} \mathrm{O}_{3}$ & 5.0 & Minimum of 70.0 \\
$\mathrm{SiO}_{2}+\mathrm{Al}_{2} \mathrm{O}_{3}=\mathrm{Fe}_{2} \mathrm{O}_{3}$ & 84.7 & - \\
Calcium-oxide & 5.2 & Maximum of 5.0 \\
Magnesium-oxide & 2.0 & - \\
Titanium-oxide & 1.27 & - \\
Potassium-oxide & .58 & Maximum of 1.5 \\
Sodium-oxide & .43 & Maximum of 5.0 \\
Sulphur-trioxide & 1.28 & Maximum of 6.0 \\
Ignition loss (1000 $\left.{ }^{\circ} \mathrm{C}\right)$ & 1.68 & Maximum of 3.0 \\
Moisture & .26 & \\
\hline
\end{tabular}

\section{Mixture proportions}

In the study, a combination M1 is planned per, IS:10262-1982 is casted and found with $28^{\text {th }}$ day strength of compression as $37.2 \mathrm{MPa}$ as a conventional concrete. The other three specimens are casted by substituting cement in concrete by 40,45 and $50 \%$ mass of Class-F fly-ash with differing superplasticizer measurements for every example projecting. Maintaining the constant quantity of additive nano-SiO2 for every sample mixture ratio. In doing as such, water-cement material proportions were kept practically same, so as to explore concrete impacts due to the substitution with high Class-F fly-ash when different boundaries are nearly maintained same. Table 6 represents the mix proportion of concrete. The Fig.1 represents the material mixing.

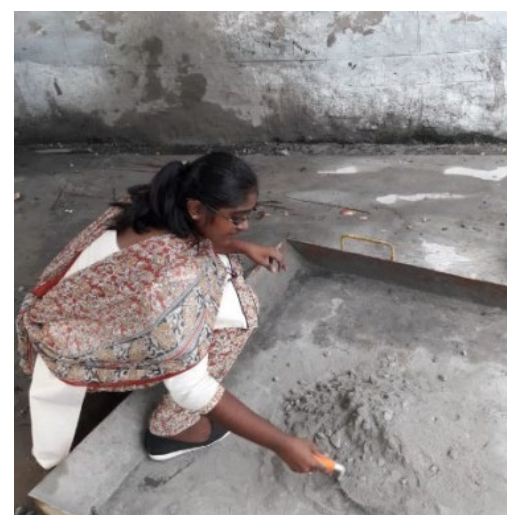

Fig. 1: Materials mixing 
TABLE 3: Aggregates physical properties

\begin{tabular}{|l|c|c|}
\hline \multicolumn{1}{|c|}{ Property } & Fine aggregate & Coarse aggregate \\
\hline Specific gravity of aggregate & 2.61 & 2.79 \\
Fineness modulus & 2.27 & 6.59 \\
SSD absorption & $0.86 \%$ & $1.10 \%$ \\
Voids & $36.0 \%$ & $39.8 \%$ \\
Unit-weight $\left(\mathrm{kg} / \mathrm{m}^{3}\right)$ & 1680 & 1613 \\
\hline
\end{tabular}

Preparing and specimens casting

Compression strength is tested with $150 \times 150 \mathrm{~mm}$ size concrete cubes. Cylinders of size $150 \times 300$ - $\mathrm{mm}$ is tested for split tensile strength, beams of $101.4 \times 101.4 \times 508$-mm is tested for flexural strength and cylinders of size $150 \times 300-\mathrm{mm}$ is used for testing elasticity modulus. Every concrete example was set up as per IS: 516-1959. In the wake of projecting, specimens are covered using plastic sheets, they are left free in projecting space for a period $24 \mathrm{hrs}$ with $24 \pm 1{ }^{\circ} \mathrm{C}$ temperature. They are demoulded after a day $(24 \mathrm{hrs})$ and are immersed into the water-storing room till the test hour. The casted specimens are shown in the Fig.2.

TABLE 4: Sieve analysis of aggregates

\begin{tabular}{|l|l|l|l|l|l|}
\hline \multicolumn{3}{|c|}{ Fine aggregate } & \multicolumn{3}{c|}{ Coarse aggregate } \\
\hline $\begin{array}{l}\text { Sieve } \\
\text { number }\end{array}$ & $\%$ passing & $\begin{array}{l}\text { IS: } 383-1970 \\
\text { Requirements }\end{array}$ & Sieve sizes & \% passing & $\begin{array}{l}\text { IS: 383-1970 } \\
\text { Requirements }\end{array}$ \\
\hline $4.75 \mathrm{~mm}$ & 95.4 & $90-100$ & $12.5 \mathrm{~mm}$ & 97 & $95-100$ \\
$2.36 \mathrm{~mm}$ & 92.7 & $85-100$ & $10 \mathrm{~mm}$ & 69 & $40-85$ \\
$1.18 \mathrm{~mm}$ & 77.0 & $75-100$ & $4.75 \mathrm{~mm}$ & 5 & $0-10$ \\
$600 \mathrm{~mm}$ & 61.1 & $60-79$ & & & \\
$300 \mathrm{~mm}$ & 34.3 & $12-40$ & & & \\
$150 \mathrm{~mm}$ & 5.7 & $0-10$ & & \\
\hline
\end{tabular}

TABLE 5: The physical properties of nano-Sio 2

\begin{tabular}{|l|l|l|l|l|l|}
\hline Type & $\begin{array}{l}\text { Total surface } \\
\text { area/unit mass } \\
\left(\mathrm{m}^{2} / \mathrm{g}\right)\end{array}$ & $\mathrm{pH}$-value & $\begin{array}{l}\text { Average size } \\
\text { of the particle } \\
(\mathrm{nm})\end{array}$ & $\begin{array}{l}\mathrm{SiO}_{2} \text { content } \\
(\%)\end{array}$ & $\begin{array}{l}\text { Density of } \\
\text { Surface } \\
(\mathrm{g} / \mathrm{ml})\end{array}$ \\
\hline Class F & $100 \pm 25$ & $6.5-7.5$ & $10-25$ & $\geq 99.7$ & $\leq 0.15$ \\
\hline
\end{tabular}

Properties of fresh concrete

Properties of Freshly casted concrete namely Slump, temperature, unit weight is determined per IS: 1199-1959. The results are tabulated in Table 6. 
TABLE 6: Concrete mixture proportion

\begin{tabular}{|c|c|c|c|c|}
\hline Mixture number & M1 & M2 & M3 & M4 \\
\hline Fly-ash & $0 \%$ & $40 \%$ & $45 \%$ & $50 \%$ \\
Cement in $\mathrm{kg} / \mathrm{m}^{3}$ & 405 & 230 & 210 & 200 \\
Fly-ash in $\mathrm{kg} / \mathrm{m}^{3}$ & 0 & 170 & 185 & 190 \\
Water in $\mathrm{kg} / \mathrm{m}^{3}$ & 165 & 161 & 165 & 161 \\
$\mathrm{~W} /(\mathrm{FA}+\mathrm{C})$ & .41 & .40 & .41 & .40 \\
$\mathrm{SSD}$ aggregate $\left(\mathrm{kg} / \mathrm{m}^{3}\right)$ & 615 & 613 & 609 & 615 \\
CA $\left(\mathrm{kg} / \mathrm{m}^{3}\right)$ & 1227 & 1225 & 1227 & 1226 \\
$\mathrm{SP}($ Superplasticizer $)\left(1 / \mathrm{m}^{3}\right)$ & 2 & 2.2 & 2.4 & 2.5 \\
Nano-Sio 2 & 20 & 20 & 20 & 20 \\
Slump in mm & 60 & 80 & 85 & 3.5 \\
Air-content in $\%$ & 3.1 & 3.5 & 3.4 & 25 \\
Air-temperature in ${ }^{\circ} \mathrm{C}$ & 26 & 25 & 27 & 29 \\
Temperature of concrete & 29 & 27 & 28 & \\
$\left({ }^{\circ} \mathrm{C}\right) \quad 2397$ & & 2401 & \\
Density of Concrete $(\mathrm{kg} / \mathrm{m} 3)$ & & & & \\
\hline
\end{tabular}

\section{Specimen testing}

Compressive strength is tested for concrete cubes of $150 \mathrm{~mm}$ normal size, split tensile strength is tested with cylinders of size $150 \times 300-\mathrm{mm}$, beams with size, $101.4 \times 101.4 \times 508-\mathrm{mm}$ is used for testing flexural strength, finally cylinder with size $150 \times 300-\mathrm{mm}$ is again used for testing the elasticity modulus in the concrete specimen as per IS:516-1959[3].

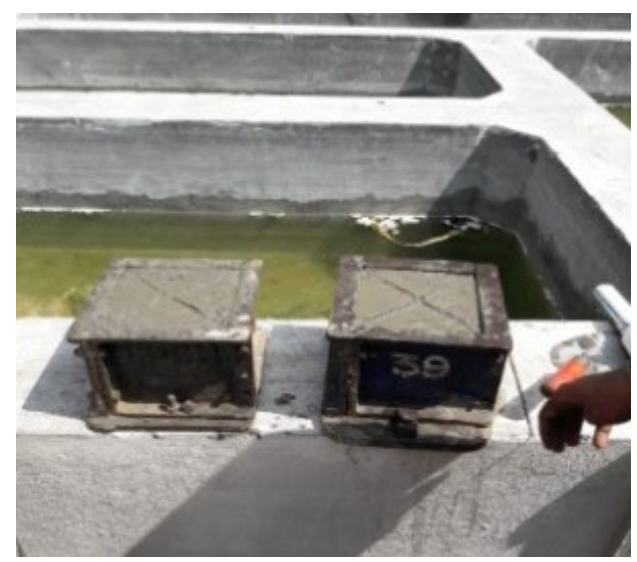

Fig. 2: Casted specimens 


\section{Discussion and results}

Compressive strength

Concrete mixture having various ages like 7,21 and 91 days were tested for compressive strength. Result obtained are tabulated in Table 7 and in Fig.3[4]. The specimen compressive strength was found to be $37.2 \mathrm{MPa}$ at the $28^{\text {th }}$ day followed by $27.5,24.3$ and $22.1 \mathrm{MPa}$ at the fly-ash replacement with percent reduction of $26 \%, 35 \%$ and $41 \%$ respectively comparing to the strength of the concrete of control mixture M1(with fly-ash 0\%). Results of compressive strength by the day 91 was found to increase gradually beyond day 28 with a varying strength increase between $21 \%$ and $26 \%$. The continued cement hydration is the main reason for the strength increase. The chemical reaction occurring by adding of pozzolans with fly-ash present in concrete is the main significant cause for the steady increase of compressive strength of HVFC. Though reduction of compressive strength occurs due to fly-ash replacement at end of 28 days the mixture M4(50\% fly-ash) might be used for the construction of concrete, M3(45\% fly-ash) and M2 (40\% fly-ash) can be used well for the structural construction of concrete[2]. This shows that the HVFC can maintain a very long-term retaining of strength.

$\boldsymbol{T A B L E} 7$ : Compression test result

\begin{tabular}{|c|c|c|c|}
\hline \multirow{2}{*}{ Mix ratio } & \multicolumn{2}{|c|}{ Compressive strength (MPa) } \\
\cline { 2 - 4 } & $7^{\text {th }}$ day & $28^{\text {th }}$ day & $91^{\text {th }}$ day \\
\hline M1 (0\% fly-ash) & 25.9 & 37.1 & 40.2 \\
M2 (40\% fly-ash) & 18 & 27.5 & 34.6 \\
M3 (45\% fly-ash) & 15.5 & 24.3 & 30.2 \\
M4 (50\% fly-ash) & 14.2 & 22.1 & 26.7 \\
\hline
\end{tabular}

TABLE 8: Result of Splitting tensile strength

\begin{tabular}{|l|l|l|l|}
\hline \multirow{2}{*}{ Mix ratio } & \multicolumn{3}{|c|}{ Splitting tensile strength (MPa) } \\
\cline { 2 - 4 } & $7^{\text {th }}$ day & $28^{\text {th }}$ day & $91^{\text {th }}$ day \\
\hline M1 (0\% fly-ash) & 2.6 & 4.1 & 4.3 \\
M2 (40\% fly-ash) & 1.7 & 3.2 & 3.9 \\
M3 (45\% fly-ash) & 1.5 & 2.7 & 3.4 \\
M4 (50\% fly-ash) & 1.4 & 2.1 & 2.7 \\
\hline
\end{tabular}




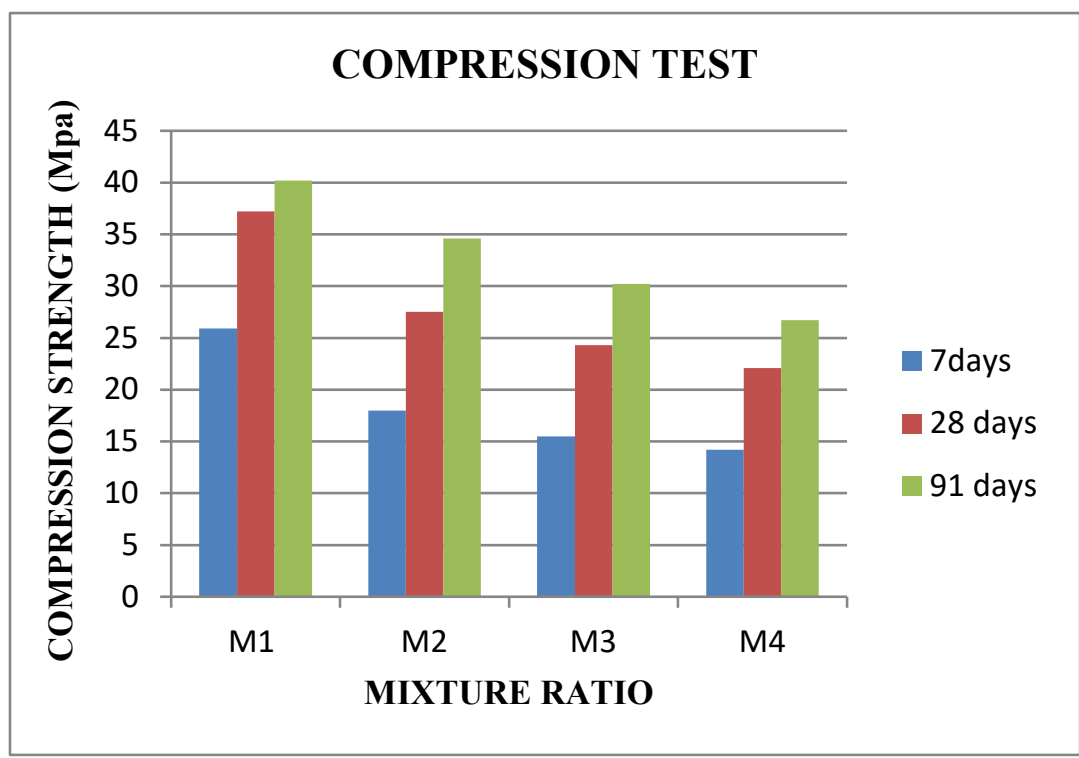

M1(0\% fly-ash) M3(45\% fly-ash)

M2(40\% fly ash) M4 (50\% fly-ash)

Fig. 3: Compressive strength vs mix proportion

Splitting tensile strength:

The splitting tensile strength of the specimen is calculated for the ages $7^{\text {th }}, 28^{\text {th }}$ and $91^{\text {st }}$ days and the results were tabulated in Table 8 and Fig. 4. The strength difference depending on ages are analysed similar to the compressive strength analysis [5]. At age 28 days the splitting tensile strength of the cylinders at M1(0\% fly-ash) was found to be 4.1 MPa followed by 3.2,2.7 and $2.1 \mathrm{MPa}$ for M2(40\% fly-ash), M3(45\% fly-ash) and M4 (50\% fly-ash) which shows the reduced strength of about $22 \%, 34 \%$ and $49 \%$ respectively. At $91^{\text {th }}$ day the strength increased to be $4.3,3.9$, 3.4 and 2.7 for M1(0\% fly-ash), for M2(40\% fly-ash), M3(45\% fly-ash) and M4 (50\% fly-ash) respectively which showed an increase of about $5 \%, 21 \%, 26 \%$ and $29 \%$ respectively when compared to the age of $28^{\text {th }}$ day. It can be observed there is a $\%$ increase in strength is much higher during 91 days and for concrete mixture M1 compared to early strength at $28^{\text {th }}$ day. This can cause pozzolanic action because of the presence of fly ash.

TABLE 9: Flexural strength results

\begin{tabular}{|l|l|l|l|}
\hline \multirow{2}{*}{ Mix ratio } & \multicolumn{3}{|c|}{ Flexural strength (MPa) } \\
\cline { 2 - 4 } & $7^{\text {th }}$ day & $28^{\text {th }}$ day & $91^{\text {th }}$ day \\
\hline M1 (0\% fly-ash) & 3.7 & 5.4 & 5.6 \\
M2 (40\% fly-ash) & 2.4 & 3.7 & 4.5 \\
M3 (45\% fly-ash) & 2 & 3.0 & 3.9 \\
M4 (50\% fly-ash) & 1.9 & 2.8 & 3.2 \\
\hline
\end{tabular}




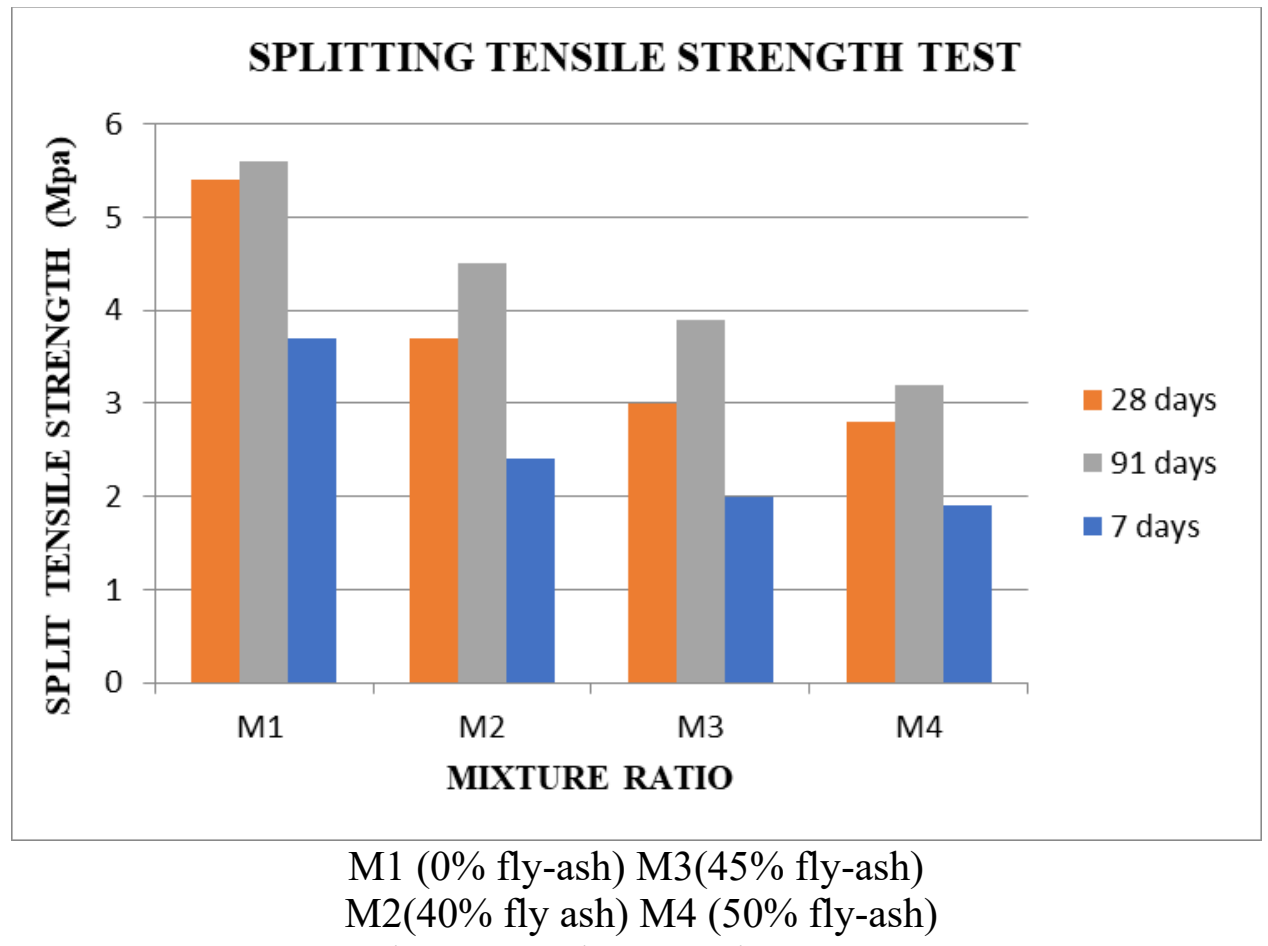

Fig. 4: Splitting tensile strength vs mix proportion

Flexural strength:

The flexural strength of the concrete specimen for $7^{\text {th }}, 28^{\text {th }}$ and $91^{\text {st }}$ days are analysed and results are presented in Table 9 and Fig. 5. Similar to the compressive and splitting tensile there is also an increase in the flexural strength with age. Control mixture M1(0\% fly-ash) was observed to have a strength of 5.4 MPa at 28 days and \%.6 MPa at 91 days which is an increase of strength. M2(40\% fly ash), M3(45\% fly-ash) and M4(50\% fly-ash) were observed with 3.7, 3 and $2.6 \mathrm{MPa}$ respectively at 28 days respectively. The strength of M2(40\% fly-ash), M3(45\% fly-ash) and M4 (50\% fly-ash) was found to possess 4.5,4,3.2 MPa respectively at 91 days which is observed to have a successive increase of strength compared to the $28^{\text {th }}$ day. It is finally observed from the results that there is a consecutive strength increase beyond $28^{\text {th }}$ day. The flexural strength of concrete from day 28-91 were found to have continuous increase between $14 \%$ and $30 \%$, depending on fly ash replacement.

TABLE 10: Results of Modulus of elasticity

\begin{tabular}{|l|c|c|}
\hline \multicolumn{1}{|c|}{ Mix ratio } & \multicolumn{2}{|c|}{ Modulus of elasticity (GPa) } \\
\hline & $28^{\text {th }}$ day & $91^{\text {th }}$ day \\
\hline M1 (0\% fly-ash) & 29.7 & 30.9 \\
\hline M2 (40\% fly-ash) & 19.8 & 22.2 \\
\hline M3 (45\% fly-ash) & 19.6 & 20.8 \\
\hline M4 (50\% fly-ash) & 18.9 & 19.1 \\
\hline
\end{tabular}




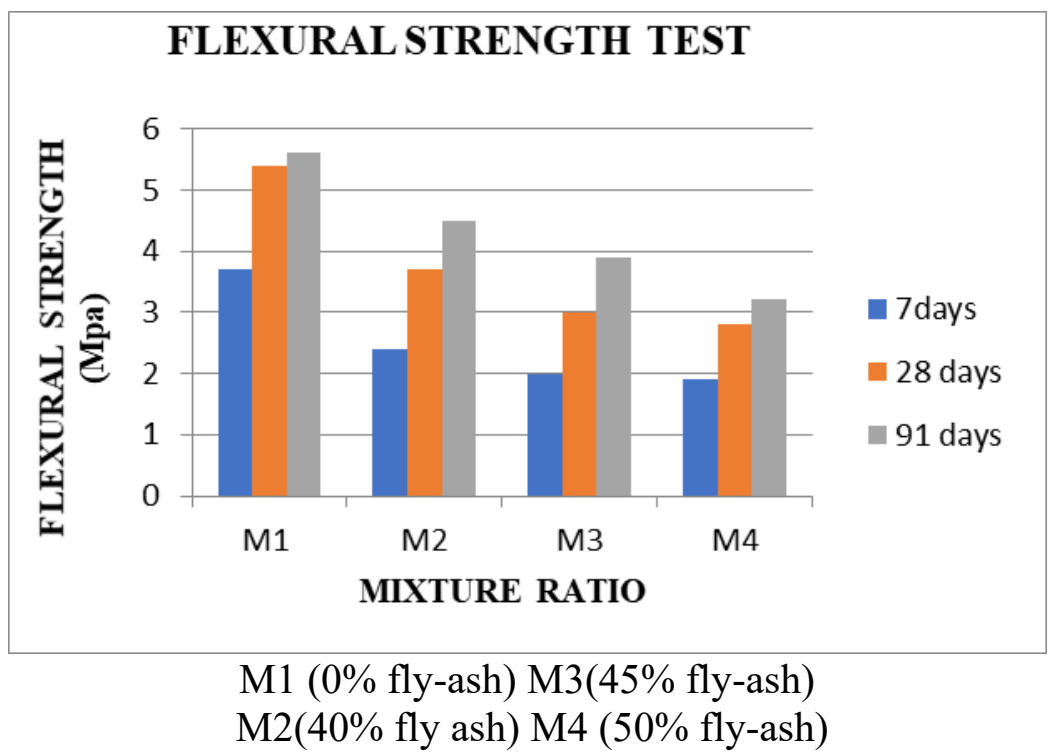

Fig. 5: Flexural strength vs mix proportion

\section{Modulus of elasticity:}

In the examination, the elasticity modulus, that additionally called secant modulus, is taken as the slant of harmony from cause to some discretionary point on the stress - strain curve. The secant modulus determined in this examination is for $33 \%$ of the most extreme pressure. Elasticity modulus for day 7,28 and 91 were observed and the results are presented in Table 10 and Fig. 6. The test results indicated that the increasing amount of fly ash decreases the modulus strength compared to that of M1 concrete mixture. The modulus value of at age 28 for M1( $0 \%$ fly-ash), M2(40\% fly-ash), M3(45\% fly-ash) and M4(50\% fly-ash) was calculated to be 29.7 , 19.8,19.6,18.9 $\mathrm{MPa}$ respectively. However, there is a successive increase in the modulus strength with ages.

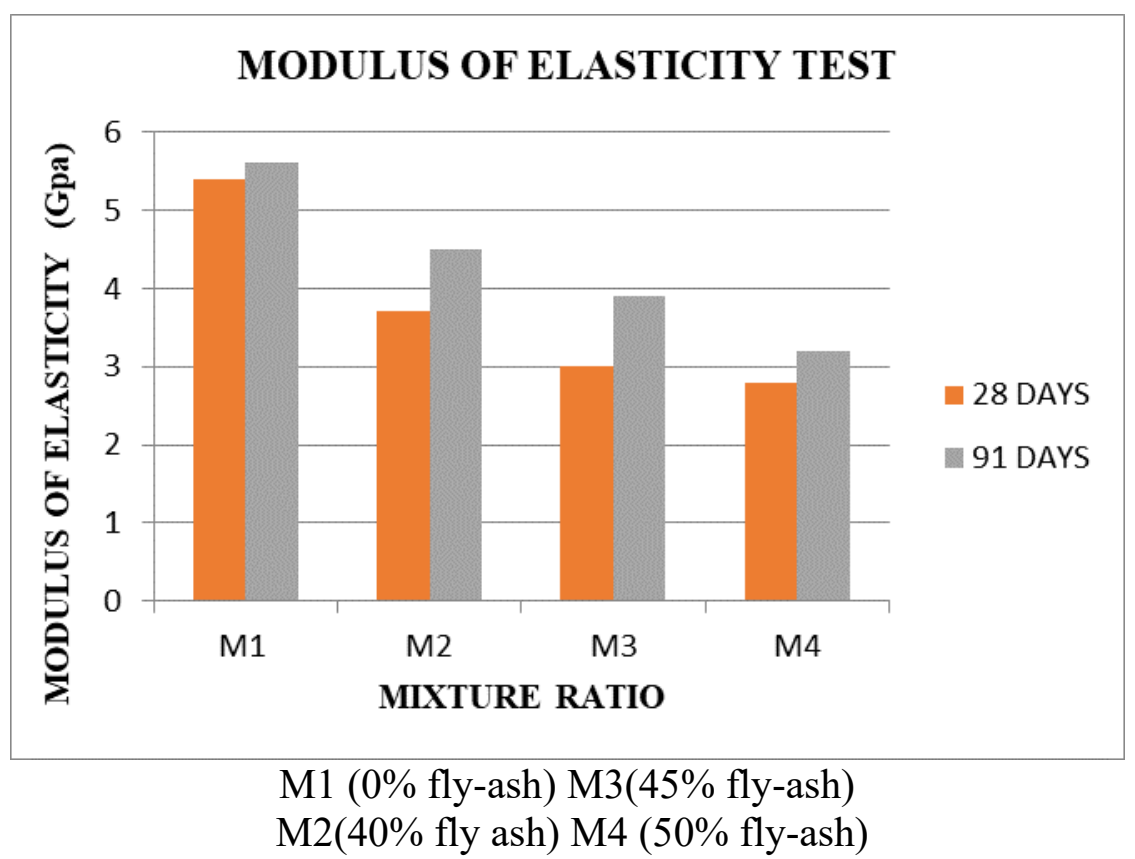

Fig. 6: Modulus of elasticity vs mix proportion 


\section{Conclusion}

The conclusion obtained from the investigation:

1. The replacement of fly ash in three different percentage at initial stage caused the decrease in strength of compression, Split tensile strength, Flexural strength and modulus of elasticity at $28^{\text {th }}$ day. But still strength gradually increased beyond $28^{\text {th }}$ day.

2. Though the concrete strength gradually decreases at $40 \%, 45 \%$ and $50 \%$ fly ash replaced concrete at 28 days has much good strength for construction of concrete structure.

3. Incorporation of nano- $\mathrm{SiO}_{2}$ into the HVFC increases both the short and long-term concrete strength.

4. Fly-ash causes high porosity at short time of curing whereas the accelerating additive nano $\mathrm{SiO}_{2}$ produce compact structure even at the shorter time of curing.

\section{References}

[1] Rafat Siddique. "Performance characteristics of high volume Class F fly ash concrete", Cement and Concrete Research, 2004. https://doi.org/10.1016/j.cemconres.2003.09.002

[2] Rafat Siddique, Kushal Kapoor, El-Hadj Kadri, Rachid Bennacer. "Effect of polyester fibres on the compressive strength and abrasion resistance of HVFA concrete", Construction and Building Materials, 2012. https://doi.org/10.1016/j.conbuildmat.2011.09.011

[3] "Waste Materials and By-Products in Concrete", Springer Science and Business Media LLC, 2008

[4] "Advances in Materials Research", Springer Science and Business Media LLC, 2021

[5] Rafat Siddique, Mohammad Iqbal Khan. "Chapter 2 Silica Fume", Springer Science and Business Media LLC, 2011. https://doi.org/10.1007/978-3-642-17866-5_2

[6] Siddique, R."Effect of fine aggregate replacement with Class F fly ash on the abrasion resistance of concrete", Cement and Concrete Research, 2003.

https://doi.org/10.1016/S0008-8846(03)00212-6 